九州大学学術情報リポジトリ

Kyushu University Institutional Repository

\title{
Notes on the family Stylodactylidae with the description of a new genus Neostylodactylus
}

Hayashi, Ken-Ichi

Zoological Laboratory, Department of Agriculture, Kyushu University

Miyake, Sadayoshi

Zoological Laboratory, Department of Agriculture, Kyushu University

https://doi.org/10.5109/22781

出版情報 : 九州大学大学院農学研究院紀要. 14 (4)，pp.583-611，1968-11. Kyushu University バージョン：

権利関係 : 
Journal of Faculty of Agriculture, Kyushu University, Vol. 14, No. 4

November 30, 1968

\section{Notes on the family Stylodactylidae with the description of a new genus Neostylodactylus ${ }^{1)}$}

\section{Ken-Ichi Hayashi and Sadayoshi Miyake}

The superfamily Stylodactyloidea is a very small group containing only one family with one genus Stylodactylus A. Milne Edwards (Holthuis, 1955). The species of this group are distinguishable from the other caridean shrimps by the following characters : the second maxilliped has the last two segments placed side by side at the end of the antepenultimate segment, the first and second pereiopods have the extremely long and slender fingers of the chela, and the third maxilliped and the first two pereiopods bear long setiferous hairs along their lower surface.

The genus was established by A. Milne Edwards (1881) on a single species, Stylodactylus serratus, collected from Dominica, West Indies. Two years later A. Milne Edwards (1883) gave figures of another Atlantic species S. rectirostris, in addition to that of the former. Bate (1888) described three new species based upon the Challenger material, S. bimaxillaris, $S$. discissipes and S. orientalis, of which the last is thought to be identical with the second. In 1920 de Man gave a list of all the species of Stylodactylus known at that time, including his two species, S. amarynthis and S. sibogae discovered in 1902 and 1918 respectively. Kemp (1925) made a revision of the genus and gave a key to all the species, including a new species $\mathrm{S}$. investiga toris. An eighth species, S. multidentatus, was described by Kubo (1942) from central Japan.

In the course of the examination of caridean shrimps from southern Japan, 19 specimens of this family were found. Special attention was given to the branchial formula and mouth-parts, which are neglected characters in most species, while these characters are needed for a better understanding of the status of some species. With the help of many colleagues we were able to re-examine or to have re-examined the branchial formulae and mouth-parts of the type specimens of all the species described, and to obtain specimens of doubtful species on loan for examination. Through the courtesy of these colleagues, a revision of this family is now completed. A

1) Contributions from the Zoological Laboratory, Faculty of Agriculture, Kyushu University, No. 387 , 
new genus, Neostylodactylus, had to be erected for one new and three known species which formerly were inserted in Stylodactylus; this new genus principally differs from the latter by the absence of the arthrobranchs on bases of the first four pereiopods.

The Japanese specimens are referred to six species, three of either genus. The species of the new genus are N. amarynthis, $N$. investigatoris and N.affinis sp. nov., of which the first two are new to the fauna of Japan; the new species is related to $\mathrm{N}$. amarynthis, but differs from it in some morphological characters. The Japanese members of the genus Stylodactylus are S. multidentatus, S. bimaxillaris and S. major sp. nov. As the first two are insufficiently known, we described these species in detail; the new species is very remarkable, having no supraorbital spine.

Recently a number of specimens labeled as S. bimaxillaris were received from the South African Museum. Of these the two smaller specimens are identical with the true S. bimaxillaris. The other, larger, specimens, however, are not identical with that species, though they were referred at first to S. serratus by Stebbing (1914) and later to S. bimaxillaris by Kemp (1925). These specimens differ from S. serratus principally in the comparative length of the third abdominal somite and the number of dorsal spines on the telson and from $S$. bimaxillaris in the absence of the mandibular palp. We propose them as a new species, S. stebbingi sp. nov., in honour of the Rev. T. R. R. Stebbing, who was the first to discover it.

In this paper we described seven species including one South African species, which may be distinguished by the following characters.

1 Arthrobranchs present on the bases of the first four pereiopods

Stylodactylus A. Milne Edwards 2

- Pereiopods without arthrobranchs ............. Neostylodactylus gen. nov ....5

2 Body larger size, $42-150 \mathrm{~mm}$. Mandibular palp present..................... 3

- Body smaller size, 19-25 mm. Mandibular palp absent ..........................

S. bimaxillaris Bate

3 Supraorbital spine present. Telson with four or five pairs of dorsal spines

- Supraorbital spine absent. Telson with 8-10 dorsal spines on either side S. major sp. nov.

4 Carapace with one branchiostegal spine but destitute of pterygostomian spine. Eye large, globular. Scaphocerite with smooth margin. Telson with five pairs of dorsal spines. Pleura of fourth and fifth abdominal somites pointed at postero-inferior angle . . . . . . . . . Stebbingi sp. nov.

- Carapace with two branchiostegal spines and one pterygostomian spine. Eye moderate, subcylindrical. Scaphocerite with a series of ten or more marginal spines. Telson with four pairs of dorsal spines. Pleura 
of all abdominal somites with smooth margins

S. multidentatus Kubo

Rostrum shorter than carapace, without teeth on the lower border...... N. investigatoris (Kemp)

- Rostrum longer than carapace, with several teeth on its lower border

6 Scaphocerite with seven rather large marginal spines. Pleura of first five abdominal somites with strong marginal spines. Sixth somite with two large outer spines. Telson with five pairs of dorsal spines. Two arthrobranchs present on base of third maxilliped.. ....... amarynthis (de Man)

- Scaphocerite with fine marginal spines. Pleura of last three abdominal somites with one small marginal spine. Sixth somite without outer spines. An arthrobranch present on base of third maxilliped

N. affinis sp. nov.

\section{Superfamily Stylodactyloidea Borradaile, 1907}

Stylodactyloida Borradaile, 1907, pp. 467, 471; Holthuis, 1955, pp. 11, 31. Stylodactyloidea Thompson, 1966, p. 318.

\section{Family Stylodactylidae Bate, 1888}

Stylodactylidae Bate, 1888, pp. 481, 850 ; Stebbing, 1914, p. 49 ; Kemp, 1925, p. 256 ; Barnard, 1950, p. 651; Holthuis, 1955, p. 31; Balss, 1957p. 1535.

\section{Genus Stylodactylus A. Milne Edwards, 1881}

Stylodactylus A. Milne Edwards, 1881, p. 11; Stebbing, 1914, p. 50; de Man, 1920, p. 31; Kemp, 1925, p. 256.

Diagnosis. Body large and robust. Rostrum elongate, with articulated teeth on dorsal and ventral margins. Carapace usually with supraorbital, antenna1 and branchiostegal spines. Hepatic groove present. Abdomen normal. Pleura with smooth margins. Telson with more than four pairs of dorsal spines. Marginal spines of scaphocerite present or absent. Mandibular palp present or absent, molar and incisor processes not clearly separated. The branchial formula is as follows:

\begin{tabular}{lccccccccc} 
& \multicolumn{3}{c}{ Maxillipeds } & \multicolumn{4}{c}{ Pereiopods } \\
& 1 & 2 & 3 & 1 & 2 & 3 & 4 & 5 \\
Pleurobranchs & - & - & - & 1 & 1 & & 1 & 1 & 1 \\
Arthrobranchs & - & - & 2 & & 1 & 1 & 1 & 1 & -- \\
Podobranchs & - & 1 & - & - & - & - & - & - \\
Epipods & 1 & 1 & - & - & - & - & - & - \\
Exopods & 1 & 1 & - & - & - & - & - & -
\end{tabular}


Type species. Stylodactyhs serratus A. Milne Edwards, 1881.

Remarks. In the present status of our knowledge, the genus Stylodactyhs contains two Atlantic species, S. serratus A. Milne Edwards and S. rectirostris A. Milne Edwards, and four Pacific species, S. discissipes Bate, S. bimaxillaris Bate, S. multidentatus Kubo and S. major sp. nov. and moreover the South African species S. stebbingi sp. nov.

The diagnosis of this genus agrees with those defined by previous authors, except for the epipods on the first four pereiopods. The presence of the epipods on the first four pereiopods has been thought to be one of the characters of this superfamily (Borradaile, 1907) and family (Balss, 1957), however, this proved incorrect. We are greatly indebted to Dr. J. Forest of the Muséum National d'Histoire Naturelle in Paris for examining the type specimen of S. serratus, the type species of this genus, and the type specimens of another Atlatic species, both proved to have no epipods on the pereiopods. Dr. A. L. Rice of the British Museum (Natural History) had the courtesy to examine the type of S. bimaxillaris, and Dr. I. Kubo of the Tokyo University of Fisheries kindly lend us the type of S. multidentatus. These two species also proved to have no epipods on the pereiopods. With regard to S. discissipes, Bate (1888) clearly figured the gill chamber of this species, which he assigned to S. orientalis and showed it to be without epipods. The new species have no epipods on the first four pereiopods either.

S. bimaxillaris is rather different from the other four species by its smaller size, the fewer rostra 1 teeth and the absence of the mandibular palp, and thereby shows some tendency to Neostylodactylus gen. nov.

\section{Stylodactylus multidentatus Kubo}

(Fig. 1)

Stylodactyhs multidentatus Kubo, 1942, p. 32, figs. 4, 5-Kumanonada, Off Mie Prefecture.

\section{Material examined.}

Kumanonada, off Mie Pref., depth 300 m, Apr. 26, 1939, 1 ovig. 우 (holotype, lent to us by Dr. I. Kubo, now deposited at ZLKU).

Bungo Channel, depth uncertain, Feb. 1959, K. Kurohara leg., 1 ð, 1 ovig. 우 (ZLKU No. 1531).

Mimase fish market, depth uncertain, K. Sakai leg., Dec. 24, 1959, 1 ठ (ZLKU No. 1897) ; Feb. 29, 1960, 2 ðぇ, 1 ovig. 우 (ZLKU No. 2019) ; Mar. 28-30, 1960, 1ð (ZLKU No. 2046).

Description. The specimens are $60-72 \mathrm{~mm}$ in body length. The rostrum is 
slender, straight and longer than the carapace. The upper border is provided with 38 to 43 close-set teeth, of which the proximal 10 to 12 are situated on the carapace. The lower border is armed with 14 to 17 similar teeth which are larger than the upper teeth. All the teeth are articulated with the rostrum.

The anterior margin of the carapace is provided with five spines on one side. The supraorbital and antenna1 spines are strong, acute and subequal in length, extending to the middle of the eyestalk. Two branchiostegal spines are also developed, the upper spine is about twice as long as the lower. The pterygostomian spine is small but conspicuous. The holotype and one male specimen collected at the Mimase fish market (ZLKU No. 2020) have only one large branchiostegal spine on the right side, though there are two spines on the left side. There is a deep hepatic groove on the carapace (Fig. la).

The abdominal somitesincluding the telson are subequal to the carapace in length including the rostrum. The third abdominal somite is not produced posteriorly. The pleura of the first five somites lack both marginal and posterior spines. That of the sixth somite is acutely triangular but the postero-inf erior angle is bluntly pointed.

The telson is twice as long as the sixth somite. It is dorsally sulcate and bears four pairs of spines on the margin of the sulcus. There is a tuft of hairs on the beginning of the sulcus. The distal margin is triangular, pointed and is provided with three pairs of spines, of which the outer is the shortest, similar to the dorsal spines and the intermediate is the longest (Fig. lb).

The eye is relatively small, without a distinct ocellus. The cornea is slightly wider than the stalk which is slender at the middle.

The antennular peduncle extends to the middle of the rostrum. The basal segment is longer than the distal two segments combined. The stylocerite is slender, acutely pointed and reaches the middle of the second segment of the antennular peduncle. The second segment is twice as long as the third segment which is armed with one or two spines in the outer part of the distal margin (Fig. lc). The proximal 30 joints of the outer flagellum are slightly thickened and bear fine setae ventrally and short marginal setae dorsally.

The scaphocerite is narrow and small, measuring approximately half the length of the carapace. It exceeds in slight extent the distal tip of the antennular peduncle. The outer margin of the scaphocerite is concave and bears a series of ten or more spines in the proximal part. One ovigerous female (ZLKU No. 2021), however, from the Mimase fish market is armed with only three (right) or nine (left) spines, besides these are so small that the margin appears smooth without any spines. The terminal spine of the scaphocerite extends far beyond the tip of the lamella. The basicerite bears no spiniform process, but there is a triangular process near 
the base of the scaphocerite. The carpocerite is large, reaching the middle of the scaphocerite. The flagellum, when complete, is about twice as long as the body.

The mandibular palp is composed of two segments, and the molar and incisor processes are fused with each other. The first maxilliped has a three-segmented endopod, the proximal and terminal segments are very short, the intermediate is much longer.

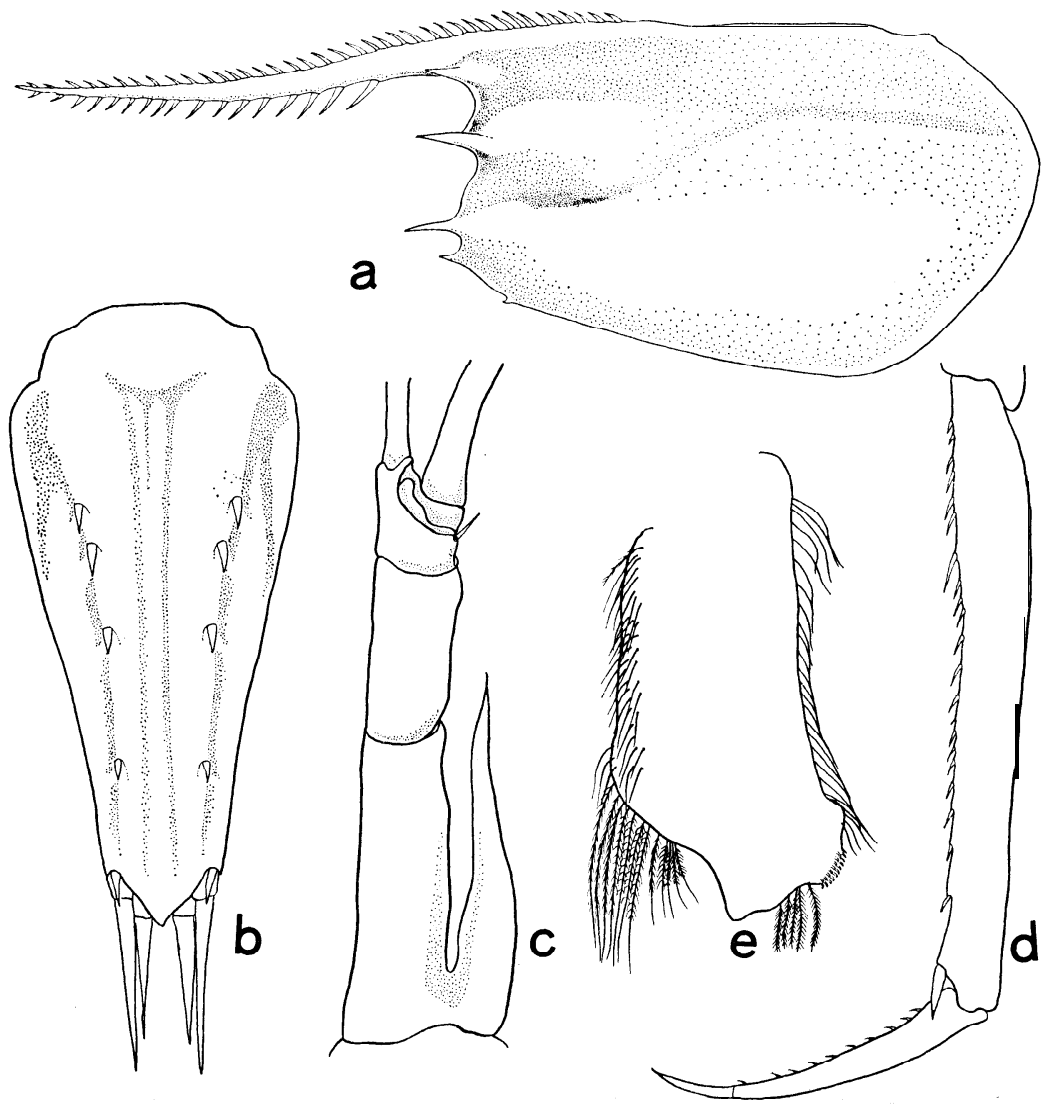

Fig. 1. Stylodactylus multidentatus Kubo.

a, Carapace and rostrum, $\times 2.3 ; \mathrm{b}$, telson, $\times 5.8 ; \mathrm{c}$, antennular peduncle, $\times 5.8 ; \mathrm{d}$, propodus and dactylus of third pereiopod, $\times 5.8$; e, endopod of first pleopod, $\times 11.6$.

The third maxilliped extends beyond the rostra1 apex by the ultimate segment. The distal three segments are subequal in length and are provided with many long setiferous hairs on the inner lower surface. The antepenul- 
timate segment is somewhat compressed and is armed with many spines over the surface, except for the upper and inner proximal part which are unarmed. There are some marginal spines on the distal articulation of the antepenultimate segment. The penultimate segment is cylindrical, with many spines scattered over the whole surface. The ultimate segment is styliform, bearing some small spines on the upper surface.

The branchial formula is typical of the genus.

The first pereiopod, which bears many long setiferous hairs on the lower surface, extends slightly beyond the distal tip of the third maxilliped. The merus is about 1.1 times as long as the chela. Numerous small spines are present on the merus in the same manner as in the antepenultimate segment of the third maxilliped, but there are no marginal spines. The carpus is shorter than the chela, with many small spines over the surface and with a rather large spine on the distal margin near the dorsal side. The chela is very slender, and the fingers are extremely long. The second pereiopod is closely similar to the first in shape and armature. The following three pereiopods are slender, all reaching the rostra1 apex. The third pereiopod is shorter than the first. There are 10 to 12 larger spines on the outer surface and a row of about 30 smaller spines on the middorsal line of the ischio-merus, of which the distal is the largest, situated on the margin. Still smaller spines and long hairs are present between these spines. The carpus is shorter than the dactylus, bearing six rather large spines on the lower margin, of which the distal form a pair. The propodus bears some short spines and long hairs dorsally and a series of spines ventrally. The dactylus is slender, long and falcate. It is more than half the length of the propodus, and is provided with ten spinules on the lower margin (Fig. Id). The fourth pereiopod closely resembles the third but is rather shorter. The merus is armed with 9 to 12 strong spines on the outer surface. The spines on the middorsal line of the merus are rather sparse and smaller than those of the third pereiopod. The fifth pereiopod is also similar to the third. A series of six to eight outer spines are present on the merus. The other small spines are very inconspicuous, and the dorsal surface is nearly glabrous. The propodus is armed with a row of spines which is larger than that of the preceding legs. The dactylus is about $1 / 5$ times as long as the propodus. The lower margin of the dactylus bears six small spines, of which the distal is much larger than the rest, and seems to be biunguiculate, having a small next to the terminal claw.

The endopod of the first pleopod in males is spatulated, with small retinacula on the inner distal corner (Fig. le). The exopod and endopod of the following pleopods are subequal in length. The appendix masculina is as long as the appendix interna, both situated on the base of the second pleopod. The endopod of the first pleopod in female is smaller than the exopod, 
but resembles it in shape. The uropod is slightly longer than the telson excluding the posterior spines. The outer margin of the exopod is setose and slightly concave in front of the broad terminal spine which at the inner side bears a movable spine, extending to the tip of the lamella.

The eggs are small and numerous, being $0.6 \times 0.8 \mathrm{~mm}$ in diameter.

Remarks. In 1942 Kubo gave an extensive description of a new species, Stylodactylus multidentatus, from Japan. Our material, however, differed rather strongly from the original description, then we requested Dr. I. Kubo to re-examine the type specimens. Owing to his kind offer, we could study the holotype of his material. The chief characters of this species, which are overlooked and mistaken in the original description, are as follows :

1) All but two of the specimens are provided on either side of the carapace with two, one large and one small, branchiostegal spines in addition to the supraorbital, antenna1 and pterygostomian spines. The exceptions are the holotype and one male specimen, which have only one large branchiostegal spine on the right side.

2) A short but deep hepatic groove is present on the carapace.

3) The dorsal margin of the telson bears four pairs of spines, excluding the posterior spine.

4) The first maxilliped has a three-segmented endopod.

5) No exopod is present on the base of the third maxilliped.

The species has been recorded from the Kumanonada, off Mie Prefecture, at a depth of about $300 \mathrm{~m}$. Our material was caught by the deep sea Danish seine fishery operating on the continental shelf of the Pacific coast of southern Japan.

\section{Stylodactylus major sp. nov.}

(Figs. 2, 3)

\section{Material examined.}

East China Sea, 30" 53.2' N, $127^{\circ} 26.0^{\prime}$ E-30" $44.0^{\prime} \mathrm{N}, 127^{\circ} 29.0^{\prime}$ E, depth $122-$ $124 \mathrm{~m}$, Dec. 5, 1967, Time 13: 50, H. Yamashita leg., 1 우 (holotype, ZLKU No. 11129), 2 우우 (paratypes, ZLKU No. 11130).

Description of holotype. The specimen is large and robust, $103 \mathrm{~mm}$ in body length (Fig. 2). The rostrum is slender, compressed and strongly curved upward. The upper border is finely serrated with 51 close-set, articulated teeth on its whole length, seven of which stand on the postrostral carina of the carapace. The lower border is armed with 30 similar teeth, the first tooth is situated above the basal segment of the antennular peduncle, and there is a short unarmed part between the distal tooth and the rostra1 apex. 
The carapace is covered with numerous fine setae, and is about 0.8 times as long as the rostrum. The supraorbital spine is absent and the antenna1 spine is small, separated from the pointed suborbital angle. The branchiostegal spine is larger and stronger than the antenna1 spine. The anterior border of the carapace between these two spines is almost straight, without any spines. The hepatic groove is well defined. The lower border of the carapace bears plumose hairs.

The abdomen is also covered with fine setae, The third somite is about three times as long as the first somite and is produced backward, with a small marginal spine on the dorsal median line. The fourth somite bears a small tooth at the postero-inferior angle. There is a large tooth at the same angle of the fifth somite. The sixth somite is long, about 2.5 times as long as the first somite. The pleuron of the sixth is small and acutely triangular, and the postero-inferior angle is provided with a strong tooth. The telson is long, about 1.8 times as long as the sixth somite. The dorsal surface is proximally ridged and suddenly sulcate. There is a tuft of hairs on the border of the ridge and the sulcus. A series of ten (right) or nine (left) dorsal spines is present along the margin of the sulcus. The distal spine is situated near the posterior margin of the telson which is sharply pointed and bears two pairs of long spines.

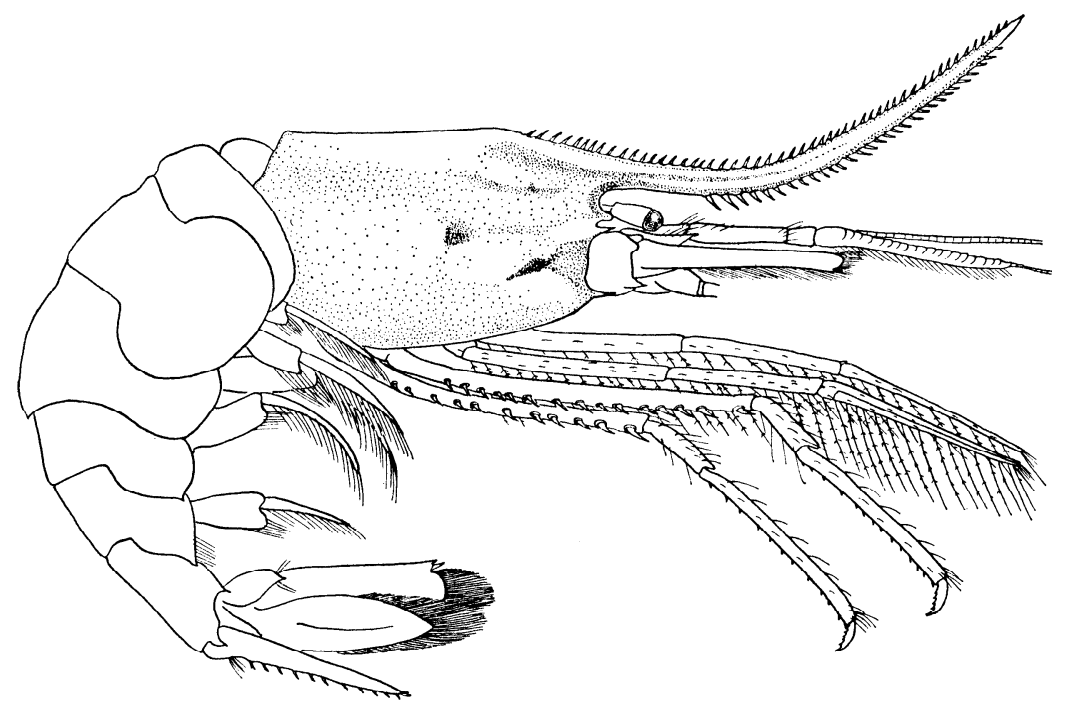

Fig. 2. Stylodactylus major sp. nov., holotype, $\times 1.1$.

The eye is moderate, subcylindrical, without a distinct ocellus. The eyestalk bears numerous short setae, being about three times as long as the cornea.

The antennular peduncle extends to half the length of the rostrum. The 
inner proximal part of the first segment is expanded below and bears a number of plumose hairs but is without any spines. The stylocerite is short, reaching slightly beyond the first segment. The second segment is longer than the first segment, more than four times as long as wide. The third segment is very short, being as long as wide. The outer antennular flagellum bears dorsally short and ventrally rather long fine setae on the proximal 24 joints.

The scaphocerite reaches beyond the antennular peduncle. It is about 3.5 times as long as wide. The outer margin is concave and ends in a distinct tooth. The lamella is rectangular at the inner distal angle which extends slightly beyond the outer spine. The carpocerite reaches the tip of the stylocerite. The basicerite bears a well-developed spine at the base of the scaphocerite, and there is a blunt process above the spine.

The mandible has a two-segmented palp, the basal segment is 2.5 times as long as the distal. There are several irregular teeth on the incisor process which is continuous with the molar process (Fig. 3a). The maxillule has a lobular proximal endite with numerous stout setae on the outer margin. The distal endite is distally broad, set with stout bristles. The palp is as broad as the proximal endite and indistinctly bilobed (Fig. 3b). The maxilla has a small, truncated proximal endite with numerous stout setae. The distal endite is deeply cleft into a larger upper and a smaller lower lobe, with closely placed short stout setae. The palp is long, taper and bears a few long plumose setae on its tip. The scaphognathite is well developed and fringed with many long filamentous hairs on the posterior lobe (Fig. 3c). The first maxilliped has a stout proximal endite and a long, large distal endite, both bearing short stout setae. The endopod is composed of three segments, the distal and proximal segments are very short, the median is much longer. The exopod is long and slender with a distinct caridean lobe. A well developed bilobed epipod is present (Fig. 3d). The second maxilliped has a great number of long, plumose hairs along the inner margin of each segment. The distal two (the inner being the longer, the outer the shorter) segments are placed side by side on the antepenultimate segment. A short exopod is present and the coxa bears a long epipod with a podobranch (Fig. 3e). The third maxilliped is long, slender and extends slightly to the rostra1 apex. It bears a series of long setiferous hairs along the inner lower surface. The ultimate segment is longer than the penultimate segment which is armed with a marginal spine on the outer distal end. Two distinct arthrobranchs are present on the third maxilliped.

The first pereiopod reaches the tip of the third maxilliped, bearing numerous long setiferous hairs on the inner lower border as in the third maxilliped. The merus is somewhat longer than the chela. The outer surface of both of the carpus and merus is sparsely setose, but without 
any spines. The carpus is about 0.6 times as long as the chela and is armed with a spine on the outer distal end. There is a deep hollow with some hairs at the inner side near the distal articulation. The chela is long and
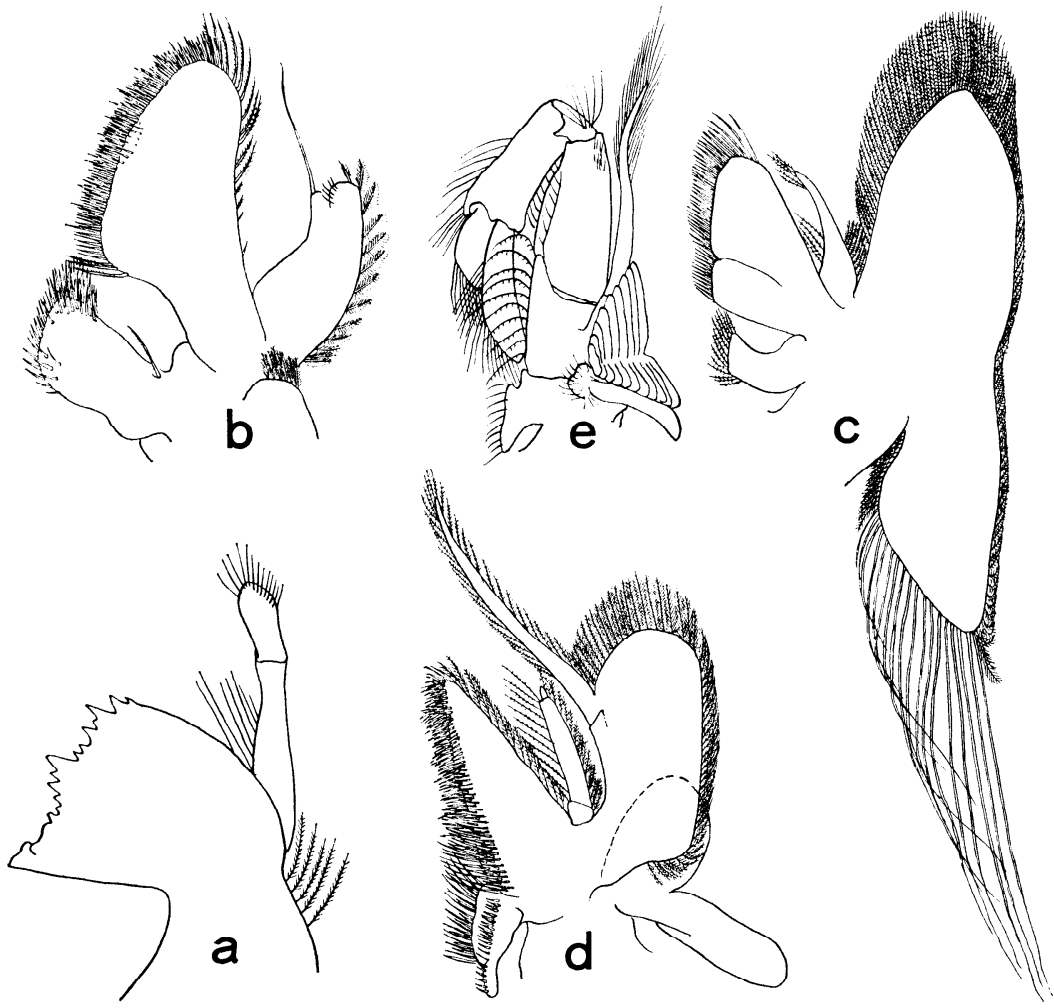

Fig. 3. Stylodactylus major sp. nov., paratype. a, Mandible, $\times 5.8$; b, maxillule, $\times 5.8$; c, maxilla, $\times 2.3$; d, first maxilliped, $\times 2.3$; e, second maxilliped, $\times 1.8$.

slender, as long as the ultimate segment of the third maxilliped. The fingers are long and terminate in some short setae. The palm is extremely short and bears a scale-like process with several plumose hairs on the lower surface. The second pereiopod resembles the first in appearance and length, but is without the deep hollow on the carpus. It reaches beyond the tip of the scaphocerite by the distal half of the chela. The third pereiopod extends to the tip of the first pereiopod. The ischio-merus is very long, about 1.8 times as long as the propodus. It is armed with 15 strong spines along the outer surface, which increase in size toward the distal spine, and with a solitary spine on the lower surface near the proximal articulation. There are fine plumose hairs on the inner upper surface of the proximal half. 
The carpus is about twice as long as the dactylus. The propodus also has many short spines on the lower margin. The dactylus is about $1 / 5$ times as long as the propodus. There are five spines except for the terminal claw on the lower margin of the dactylus. The fourth pereiopod is very similar to the third leg, extending beyond the tip of the scaphocerite by the dactylus and the half the propodus. The merus is shorter than that of the third pereiopod. It has 11 outer spines along its whole length, but is without the solitary spine and plumose hairs. The propodus is slightly longer than that of the third leg. The dactylus bears five spines excluding the terminal claw, as in the third leg. The fifth pereiopods are both missing.

The first pleopod has the endopod ovate without retinacula, about $1 / 3$ of the length of the exopod. The following four pleopods are similar in shape and length; the endopod is as long as the exopod with a rod-like appendix interna bearing retinacula in the inner distal part. The uropod is slightly longer than the telson, excluding the posterior spine. The outer margin of the exopod is almost straight and ends in a tooth with a longer movable spine immediately inner.

Paratypes. The paratypes are larger than the holotype, measuring 130 $\mathrm{mm}$ and $150 \mathrm{~mm}$ in body length. The rostrum is proximally broken in both specimens. There are nine or ten close-set teeth on the carapace. The third abdominal somite is armed with three or four small spines on the posterior end of the tergum. The telson is armed with nine or ten (right) and eight or nine (left) dorsal spines. The pereiopods are all missing in one specimen but the right third and the left fourth pereiopods are attached in another specimen. These legs are similar to those of the holotype. The merus of the third pereiopod is armed with 16 outer and one solitary spine. The merus of the fourth pereiopod bears 12 outer spines.

Remarks. The species may be distinguished from the other members of this family by the following three characters.

1) S. major has no supraorbital spine, while the other species of the present family bear a rather small but distinct supraorbital spine.

2) On the third abdominal somite in the new species there are a few (one to four) small marginal spines which are entirely absent in other species.

3) The telson has eight to ten dorsal spines on either side in this new species, while the other species have three to five pairs of spines on the telson.

The new species was collected in the East China Sea at a depth of 122 to $124 \mathrm{~m}$ by the research vessel "Kaiyo Maru" during the survey for the exploitation of new fishing grounds, which was carried out by the Seikai Regional Fisheries Research Laboratory, Nagasaki. 'The survey is designed to explore the edge of the continental shelf of the East China Sea from 
south of the Goto Islands to north of Formosa.

The three specimens of this species were obtained from a single trawl haul, and the associated caridean shrimps collected from the same haul were Heterocarpus dorsalis Bate, Pandalopsis sp. and Acanthephyra eximia Smith.

\section{Stylodactylus stebbingi sp. nov.}

(Fig. 4)

Stylodactylus serratus : Stebbing, 1914, p. 51, pl. 12-Buffalo River, NW. 1/2 W., 19 miles, East London (non Stylodactylus serratus A. Milne Edwards).

Stylodactylus bimaxillaris: Kemp, 1925, p. 257-no new locality (in part) ; Barnard, 1950,p.652, fig. 122, f-h-Off Cape Morgan, off Cape Peninsula (non Stylodactylus bimaxillaris Bate).

\section{Material examined.}

Off Buffalo River, NW. 1/2 W., 19 miles, East London, Cape Colony, depth 300 fms., 1 ð (holotype), 1 ovig. 우 (paratype, Cat. Nos. S.A.M. A 1285 and 1286)

Off Buffalo River, 300 fms. and off South Head, 190 fms., South Africa,

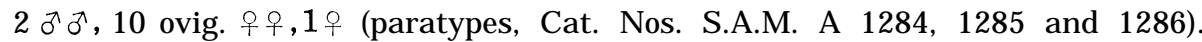

The type material is deposited at the South African Museum, with the exception of one male which has been donated to the Zoological Laboratory, Kyushu University (ZLKU No. 11181). These South African specimens were previously examined by Stebbing (1914) and Barnard (1950).

Description of holotype. The holotype (male) is $42 \mathrm{~mm}$ in body length (Fig. 4). The rostrum is slender, straight and 1.4 times as long as the carapace. The upper border is armed with 39 articulated close-set teeth on its whole length, seven of which are situated on the carapace. There are 23 similar teeth on the lower border.

The supraorbital spine is very small, situated on the upper margin of the orbit, and the suborbital angle is bluntly produced. The antenna1 spine is well developed and the branchiostegal spine is slightly shorter than the antenna1 spine. The margin between these two spines is convex. The pterygostomian angle is rounded. The hepatic groove is short but deep.

The third abdominal somite is about 3.8 times as long as the first somite and is produced over the anterior portion of the fourth somite. The pleuron of the fourth somite bears a small spine at the postero-inferior angle. That of the fifth somite is also armed with a well-developed spine. The sixth somite is 2.8 times as long as the first somite. The pleuron of the sixth somite is triangular, with a small spine and the postero-inferior angle is armed with an acute spine. The telson is 1.7 times as long as the 
sixth somite. It is sulcate proximally and flattened distally, with five (right) and six (left) dorsal spines. The posterior margin bears a median acute point which is flanked by three pairs of spines, the outer of which is very short, being similar to the dorsal spines, the median is the longest being about twice as long as the inner.

The eye is large and globular and the cornea is much wider than the stalk. The ocellus is distinct, it is in contact with the cornea.

The antennular peduncle fails to reach the middle of the rostrum. There is a series of plumose hairs on the lower surface of the first segment. The stylocerite is slender, reaching slightly beyond the distal articulation of the first segment. The second segment is twice as long as the third. The outer antennular flagellum is thickened and setose in the proximal 22 joints.

The scaphocerite is narrow, about 6.5 times as long as wide. The terminal spine on the outer margin extends beyond the tip of the lamella. The basicerite is armed with a distinct spine on the outer side. The carpocerite extends one-third length of the scaphocerite.

The mandibular palp is two-segmented, it has been described and figured by Stebbing (1914) and Barnard (1950).

The distal two segments of the third maxillipeds are both missing. The antepenultimate segment is provided with numerous long setiferous hairs on the lower surface and with several small spines on the outer surface, but its dorsal margin is glabrous.

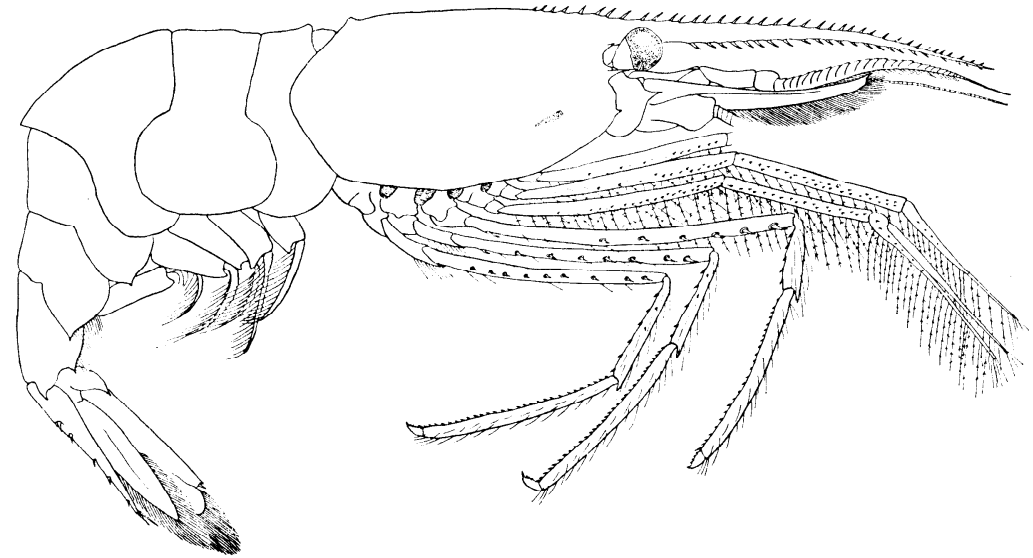

Fig. 4. Stylodactylus stebbingi sp. nov., holotype, $X$ 2.3.

The branchial formula is typical for the genus.

The first pereiopod exceeds the rostra1 apex by the distal two-thirds of the chela and is armed with long setif erous hairs on the lower margin. The merus is 2.3 times as long as the chela and bears sparsely small spines 
on the outer surface. The carpus is slightly longer than the chela and is provided with numerous fine hairs and short spines. The third pereiopod exceeds the rostra1 apex by the dactylus and the half the propodus. The ischio-merus is 3.6 times as long as the carpus and is armed with six spines on the outer surface, it bears two spines on the lower surface near the proximal articulation. The carpus is about half the length of the propodus, with several long hairs and short spines. The propodus is 5.7 times as long as the dactylus, with 24 spines on the lower margin. The dactylus bears five (right) and four (left) spines excluding the terminal claw on the lower margin. The fourth and fifth pereiopods are similar to the third leg and both extend to the rostra1 apex by their dactylus. The merus of the fourth leg is shorter than that of the third leg, and is armed with seven (right) and eight (left) outer spines and one solitary spine on the lower proximal surface. The propodus and carpus of the fourth pereiopod are slightly longer than those of the third pereiopod. The dactylus of the fourth pereiopod is armed with five spines on the lower margin excluding the terminal claw. The nine outer spines are present on the merus of the fifth pereiopod but the solitary spine is absent. The propodus and carpus of the fifth pereiopod are also longer than those of the fourth leg.

The first left pleopod is missing. The endopod of the right is spatulated, but its distal tip is damaged. The uropod is longer than the telson. The outer margin of the exopod is straight, setose and ends in a small spine, with a longer mobile spine immediately inside.

Paratypes. The paratypes consist of two males, eleven ovigerous females and one female in a size range of 28 to $52 \mathrm{~mm}$ in body length. Ovigerous females are rather larger than males. The rostrum is broken in all but four specimens, in which the rostrum is 1.4 to 1.9 times as long as the carapace and bears 37 to 40 upper and 19 to 25 lower teeth. There are six to nine teeth on the carapace behind the orbit. The telson bears five pairs of dorsal spines in all but two specimens. In these two exceptional specimens there are abnormally four or six dorsal spines on one side.

The upper antennular flagellum has the proximal 17 to 33 joints swollen and setose ventrally. It is slenderer in females than in males. The scaphocerite is 6.3 to 7.7 times as long as wide.

The third maxilliped and the following five pereiopods are almost detached from the body. The descriptions are depend on a few attached legs. There are seven outer and two lower spines on the merus of the third pereiopod. The merus of the fourth pereiopod bears eight to ten outer spines and one lower spines and that of the fifth pereiopod bears seven to nine outer spines. A series of 24 to 26 spines are present on the propodi of the last three pereiopods. The dactyli of these three pereiopods bears five spines excluding the terminal claw, 
Remarks. The South African specimens could be examined, through the courtesy of Dr. B. F. Kensley of the South African Museum. The new species was at first identified with the Atlantic S. serratus by Stebbing (1914). In $1925 \mathrm{Kemp}$, however, transferred it to S. bimaxillaris and Barnard (1950) followed him. The present species indeed is closely related to S. serratus and $S$. bimaxillaris, and also to the Pacific S. discissipes Bate which is closely allied to S. serratus. However, S. stebbingi seems to differ from all these species. The differences between $\mathrm{S}$. stebbingi and $\mathrm{S}$. bimaxillaris are following.

1) S. bimaxillaris is 19 to $26 \mathrm{~mm}$ long, provided with 25 to 35 teeth on the upper border and with 5 to 8 teeth on the lower border of the rostrum. The South African species grow up to $45 \mathrm{~mm}$ ( $\left.\sigma^{\top}\right)$ and $55 \mathrm{~mm}$ ( o f) and there are 31 to 34 rostra1 teeth on the upper and 17 to 23 on the lower border.

2) In S. stebbingi the postero-inferior angle of the fourth abdominal pleuron is provided with a small sharp point like that of the fifth somite. In $\mathrm{S}$. bimaxillaris it is smooth, without any point, but the fifth somite is usually with the pointed postero-inf erior angle.

3) In S. bimaxillaris the eye is long and subcylindrical, and there is a small process with a few spines on the lower surface of the middle of the stalk. In S. stebbingi the eye is large and globular without any process on the stalk.

4) The first segment of the antennular peduncle of S. bimaxillaris is armed with a small spine on the lower margin near the distal articulation. In S. stebbingi the lower margin of the first segment bears numerous plumose hairs but lacks any spines.

5) In S. stebbingi the stylocerite extends to the distal articulation of the first segment of the antennular peduncle. It reaches only the middle of the first segment in S. bimaxillaris.

6) S. stebbingi has a longer scaphocerite, being as long as the carapace. In S. bimaxillaris the scaphocerite is half the length of the carapace.

7) Dr. A. L. Rice, who kindly re-examined the type specimen of S. bimaxillaris found that it has no mandibular palp. Such a palp is also missing in our material, while S. stebbingi has a distinct palp of two segments.

The following two differences between S. stebbingi and S. serratus are found. A direct comparison, however, will probably show more differences between them.

1) The third abdominal somite is large, more than twice as long as the second somite and produced over the base of the fourth somite in S. stebbingi. In S. serratus the third somite is as long as or slightly longer than the second somite and is not produced posteriorly.

2) The telson bears five pairs of dorsal spines in S. stebbingi and four pairs in S. serratus.

Dr. R. W. Ingle of the British Museum (Natural History) kindly examined 
the type specimens of S. discissipes and S. orientalis for us and found that the differences between S. stebbingi and S. discissipes are even more distinct. The comparative length of the third abdominal somite and the number of dorsal spines on the telson of $\mathrm{S}$. discissipes are same as in S. serratus. Further the features of the scaphocerite are same as in S. bimaxillaris. In addition to those characters the following difference may be noted.

1) In S. stebbingi the pleura of the fourth and fifth abdominal somites are acutely pointed at the postero-inferior angle. In S. discissipes they are entirely rounded without any trace of pointed tips.

\section{Stylodactylus bimaxillaris Bate}

(Fig. 5)

Stylodactylus bimaxillaris Bate, 1888, p. 855, pl. 138 fig. 3-Off Admiralty Is, ; Kemp, 1925, p. 257-no new locality (in part).

? Stylodactylus bimaxillaris : Balss, 1914, p. 27-Sagami Bay, Japan ; Balss, 1925, p. 239--Zanzibar Channel, 5" 27' S, 39" 1.8' E ; Yokoya, 1933, p. 15-Southern Bungo Strait, 32" 51' 35" N, 132" 22'55” E, South-west of Goto Is., 32” 12' 15" N, 128" 06' 30" E ; Calman, 1939, p. 188-Gulf of Aden, Zanzibar area. non Stylodactylus bimaxillaris : Barnard, 1950, p. 652, fig. 122, f-h.

\section{Material examined.}

East China Sea, 31'31.7' N, 127' 27.4' E, depth 128 m, July 9, 1962, Time 11 : 17, H. Yamashita leg., 1 ovig. 우 (ZLKU No. 11121) ; 31" 09.5' N, 127” 16.0' E, depth $111 \mathrm{~m}$, March 26,1964, Time 16: 35, H. Yamashita leg., 1 ovig. 우 (ZLKU No. 11122).

Korea Strait, 34" 25.3' N, 129" 05.4' E, depth 150 m, June 16, 1964, Time 10 : 00, H. Yamashita leg., 1 ㅇ (ZLKU No. 11123).

Off Lourence Marques, Mozanbique, $25^{\circ} 07^{\prime} \mathrm{S}, 34^{\circ} 34^{\prime} \mathrm{E}$, depth $112 \mathrm{~m}$, Aug. 19, 1964, 1 ovig. 우 (Cat. No. PED 19y-z) ; Off Durban, South Africa, 29" 34' $\mathrm{S}, 31^{\circ} 39^{\prime} \mathrm{E}$, depth $118 \mathrm{~m}$, Sept. 9, 1964, 1 ð (Cat. No. NAD 40w).

Description. The five specimens are 19 to $25 \mathrm{~mm}$ in body length. The rostrum is about 1.5 times as long as the carapace. It runs downward for about its half length, while the distal part is more or less upturned. On the upper border there are 25 to 34 articulated teeth which are decreasing in size distally. Of these teeth the proximal six are situated on the carapace each with very long plumose hairs at the base. The lower border is armed with five to seven similar teeth in the central part, so that the proximal and the distal third are unarmed. The supraorbital spine is very small and short. The suborbital is bluntly pointed and is separated from the acute antenna1 spine by a notch. The anterior margin of the carapace is rather convex between the antenna1 and pterygostomian spines but without any trace of a spine (Fig. 5a). 
The third abdominal somite is produced posteriorly. The pleuron of the fifth somite is bluntly pointed at the postero-inferior angle. The sixth somite is about 1.6 times as long as the fifth somite. Its pleuron is triangular with a sharp spine, and the postero-lateral angle is bluntly pointed (Fig. 5b). The telson is 1.3 times as long as the sixth somite. There are five (three specimens) or six (one) pairs of spines on the margin of the shallow sulcus of the telson. The posterior margin is acutely pointed and bears three spines and a few plumose hairs on either side of the apex.

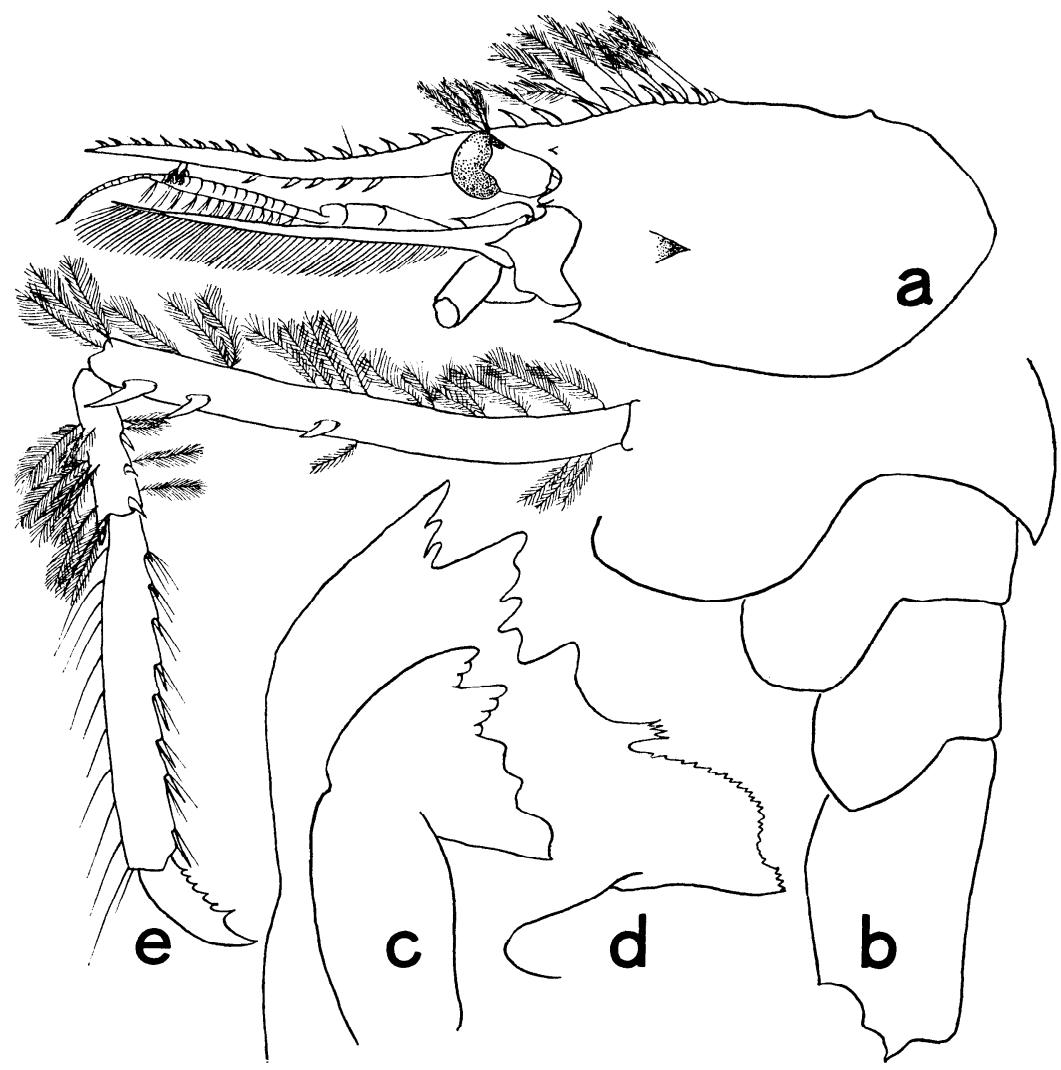

Fig. 5. Stylodactylus bimaxillaris Bate

$\mathrm{a}$, Anterior part of body, $\mathrm{x} 6.8$; $\mathrm{b}$, third to sixth abdominal somites, $\times 11.3$; c, mandible of Bate's type sketched by A. L. Rice; d, mandible of Japanese specimen, $\times 46.8$; e, third pereiopod, $\times 11.3$.

The eye is long and subcylindrical, with a distinct ocellus. The cornea is set obliquely on the eyestalk, with a tuft of plumose hairs near the ocellus. There is a small process with a few spines on the lower surface of the stalk. 
The antennular peduncle is narrow, reaching half the length of the rostrum. The basal segment is about 4.4 times as long as the second segment. It bears a small spine and two long hairs on the inner lower surface near the distal articulation and some plumose hairs follow them. The outer margin of the stylocerite is straight and ends in a spine which extends to the middle of the basal segment. The antennular flagella are both not so long, and extend slightly beyond the tip of the scaphocerite. The proximal 15 joints of the outer flagellum bear fine setae ventrally.

The scaphocerite is about eight times as long as broad, and reaches beyond the rostra1 apex. The outer side is concave without any spines and ends in a strong spine which extends far beyond the lamella. The basicerite is armed with a spine on the outer distal end at the base of the scaphocerite. The carpocerits is small and extends to the end of the proximal fifth of the scaphocerite.

The mandible is different from that of the previous three species by the absence of the palp. The molar and incisor processes are not separated (Fig. 5c, d).

The third maxilliped is long, exceeding the rostra1 apex by the ultimate segment. The lower border bears long setiferous hairs similar to the following two pereiopods. The distal three segments are subequal in length. The penultimate segment bears some hairs on the outer surface, and the antepenultimate has a series of spinules on the outer surface.

The branchial formula is similar to that of the previous three species, but one of the arthrobranchs on the third maxilliped is smaller than the other.

The first pereiopod exceeds the rostra1 apex by two-thirds of the chela. The chela is as long as the merus which bears numerous spinules on the outer side. The second pereiopod is similar to the preceding leg, reaching the rostra1 apex. The third pereiopod is robust, extending to the tip of the antenna1 scale. The merus is long, covered with long plumose hairs on the dorsal surface, and is armed with three long spines on the outer surface, the distal two are placed near the articulation and the proximal one in the middle of the segment. There are three small spines on the outer lower surface of the carpus. The propodus is three times as long as the carpus, with several spines concealed by many hairs on the lower margin. The dactylus is armed with five or six spines excluding the terminal claw on the lower margin (Fig. 5e). The fourth and fifth pereiopods resemble the third in general form. The merus of the fourth leg bears two to four spines and that of the fifth leg has two to five similar spines.

The pleopods and uropod are normal in shape.

The eggs are small, measuring 0.5 × $0.7 \mathrm{~mm}$.

Remarks. The material examined, one male and four females including three ovigerous, agree with the type description given by Bate (1888). 
He originally described the species from the Admiralty Islands, $1^{\circ} 54^{\prime} 00^{\prime \prime}$ $\mathrm{S}, 146^{\circ} 39^{\prime} 40^{\prime \prime} \mathrm{E}$. The subsequent authors recorded material, under the name $S$. bimaxillaris, from Japan, the western part of the Indian Ocean, and the east coast of Africa, but there are some doubts as to the correctness of the identification of these specimens. As the Japanese specimens recorded by Balss (1914) and Yokoya (1933) were not described in detail, we can not positively refer them to this species. The same is in true for the material dealt with by Balss (1925) and Calman (1939).

The South African specimens of this species were collected from the south western part of the Indian Ocean during the ecological survey of the University of Cape Town. They differ in some respects from those taken in Japanese waters. The rostrum in South African specimens has 31 and 34 dorsal teeth and in Japanese specimens 25 and 26. The merus of the fifth pereiopod in a specimen from South Africa has five outer spines, while that of the Japanese specimens bears only two spines. The fourth pereiopod has the merus with four outer spines in the South African specimen and with two or three spines in the Japanese specimens.

On the other hand, the South African specimens of $S$. bimaxillaris differ from the species assigned by Barnard (1950) to S. bimaxillaris, which species is described above as S. stebbingi sp. nov. The differences between the two species are discussed in the account for $S$. stebbingi.

\section{Neostylodactylus gen. nov.}

Diagnosis. Body small. Rostrum elongate, upper border with teeth ; lower border with teeth or smooth. Carapace with supraorbital, antenna1 and pterygostomian spines. Abdomen strongly bent backward and first somite very narrow. Margins of pleura serrated or smooth. Telson with three or five pairs of dorsal spines. Marginal spines of scaphocerite present or absent. Mandibular palp absent, molar and incisor processes not clearly separated. One or two arthrobranchs on third maxilliped. Pereiopods without arthrobranchs, exopods and epipods.

Type species. Stylodactylus amarynthis de Man, 1902.

Remarks. The new genus Neostylodactylus is distinguishable from the genus Stylodactylus by the smaller size, the absence of arthrobranchs on the first four pereiopods and the absence of a mandibular palp. In the new genus are included four species, viz., N. amarynthis (de Man), N. affinis sp. nov., N. investigatoris (Kemp) and $\mathrm{N}$. sibogae (de Man).

The last species was not examined by us. However, through the courtesy of Dr. Jan H. Stock of the Amsterdam Museum and Dr. Lipke B. Holthuis of the Rijksmuseum van Natuurlijke Historie, Leiden, the type specimen 
of $N$. sibogae was examined, and proved to bear no arthrobranchs on all the pereiopods.

\section{N eostylodactylus amarynthis (de Man)}

(Fig. 6)

Stylodactylus sp. (amarynthis) de Man, 1902, p. 897, pl. 27 fig. 64-Ternate.

Stylodactylus amarynthis : de Man, 1920, p. 32, pl. 5 fig. 9-9h-Siboga station 33,

Bay of Pidjot, Lombok, Station, 65a, near 7" $00^{\prime} \mathrm{S}, 120^{\circ} 34.5^{\prime}$ E, Station 204, 4" 20' S, 122" 58' E ; Kemp, 1925, p. 258-Ross Channel, Port Blair, Andaman Is. ; Holthuis, 1955, fig. 12 ; Balss, 1957, fig. 1537.

\section{Material examined.}

Off Tomioka, Amakusa Is., Kumamoto Pref., gill net, depth 30-60 m, Feb. 1966, A. Taki leg., 1 ovig. 우 (ZLKU No. 3331).

Description. The specimen is about $17 \mathrm{~mm}$ in body length, with plumose hairs on some parts of the carapace and abdomen. The apex of the rostrum is broken; on the remaining part of the upper border there are only 12 teeth, of which four are situated on the carapace. On the lower border of the rostrum there are five teeth. All the teeth are articulated with the rostrum (Fig. 6).

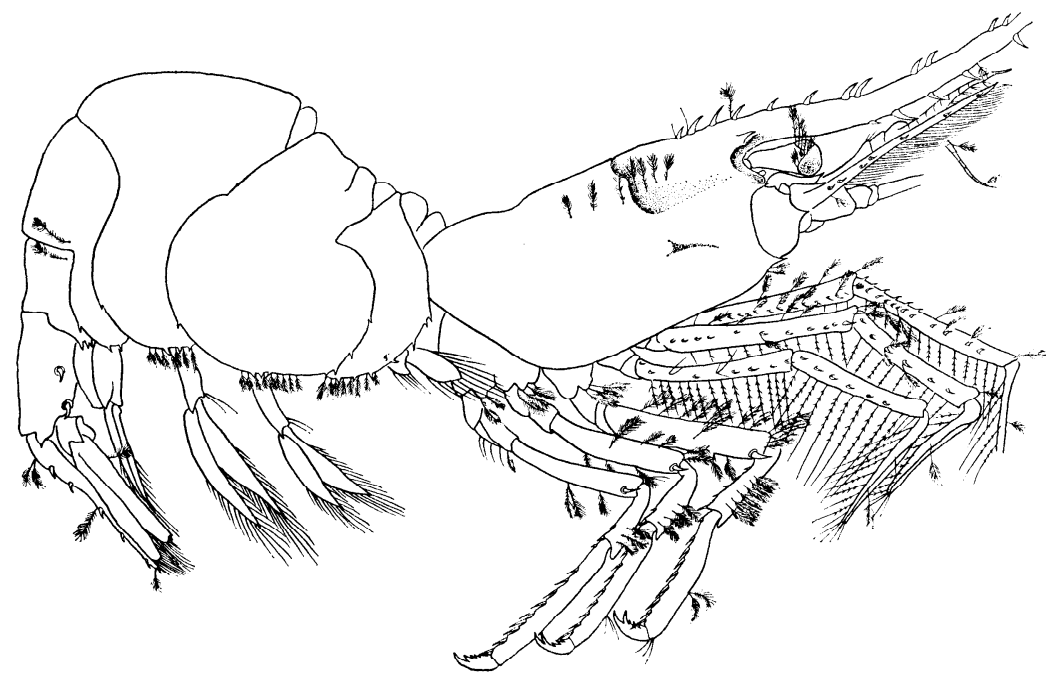

Fig. 6. Neostylodactylus amarynthis (de Man), $\times 6.8$.

The carapace is flattened above, especially in the cardiac region, and the postero-lateral margin of the carapace is produced posteriorly. Supraorbital, antenna1 and pterygostomian spines are present. A hepatic groove 
is also present on the carapace.

The pleura of the first to fifth abdominal somites are armed with small marginal spines, which number in the respective segments, seven, eight, four, three and three. The first somite is very narrow dorsally. The sixth somite is provided with two outer spines, one is placed on the middle portion of the segment, the other is on the distal extremity. There are five pairs of dorsal spines on the telson.

The eye is moderate in size with a distinct ocellus. There are long plumose hairs around the border between stalk and cornea. The inner basal part of the stalk is slightly swollen with a few small spines.

The basal antennular peduncle is armed with a forwardly directed spine on the distal three-fourths of the inner lower margin and a long hair just behind it.

There is a series of seven teeth on the outer margin of the scaphocerite. The mandible is not provided with a palp.

The branchial formula is as follows :

\begin{tabular}{lcccccccc} 
& \multicolumn{3}{c}{ Maxillipeds } & \multicolumn{3}{c}{ Pereiopods } \\
& 1 & 2 & 3 & 1 & 2 & 3 & 4 & 5 \\
Pleurobranchs & - & - & - & 1 & 1 & 1 & 1 & 1 \\
Arthrobranchs & - & - & 2 & - & - & - & - & - \\
Podobranchs & & 1 & - & - & - & - & - & - \\
Epipods & 1 & 1 & - & - & - & - & - & - \\
Exopods & 1 & 1 & - & - & - & - & - & -
\end{tabular}

One of the arthrobranchs on the third maxilliped is smaller than the other as in S. bimaxillaris.

The armature and length of the third maxilliped and following five pereiopods agree well with the description of those given by de Man (1920). The third and fourth pereiopods are fringed with some plumose hairs on each merus and carpus.

The eggs are numerous and small, $0.5 \mathrm{~mm}$ in diameter.

Remarks. The material can be identified with the present species for $\mathrm{i}^{+} \mathrm{s}$ diagnostic features of the rostrum and abdominal pleura. But the number of spines on the rostrum and pereiopods in our material is rather fewer than those of Kemp's (1925) specimens from the Andaman Islands.

According to Mr. A. Taki, this specimen was found in the sea weeds, corals, sponges, bryozoans, sea-fans, cork-polyps etc., which get entangled in the gill nets used for catching spiny lobsters. This species, therefore, probably lives associated with sea weeds or sessile marine invertebrates. Other crustaceans obtained together with this species are commensal shrimps belonging to the genus Synalpheus and to the subfamily Pontoniinae. 
This species is new to the Japanese fauna reaching here the northernmost point of its known range; so far it has been recorded only from some points of the Malay Archipelago and the Andaman Islands at depths varying between 5 and 218 fms.

\section{Neostylodactylus affinis gen. et sp. nov.}

(Fig. 7)

\section{Material examined.}

Korea Strait, 33” 34.9' N, 128 25.2' E, depth 120 m, June 18, 1964, Time 19 :18, H. Yamashita leg., 1 우 (holotype, ZLKU No. 11124), 3 ovig. 우우(paratypes, ZLKU No. 11125).

Description of holotype, The specimen is $15 \mathrm{~mm}$ in body length. The rostrum is long, strongly curved upward and extends distinctly beyond the scaphocerite. The upper border is provided with 20 articulated teeth. The proximal 11 teeth, including nine on the carapace, are placed close to each other with some plumose hairs on the base. There are five similar teeth on the lower border, of which the first tooth is implanted just above the distal margin of the first segment of the antennular peduncle. The following three are separated by uniform distances from each other. The distal stands somewhat farther apart from the others.

The carapace is more than half the length of the rostrum. The suborbital angle is produced into a long process, notched by the antenna1 spine. The small supraorbital and pterygostomian spines are present. The cervical groove is ill defined but the hepatic groove is prominent (Fig. 7a).

The abdomen is strongly bent backward as in the former species. The first somite is very narrow dorsally. The pleura of the first two somites are broadly rounded. There is one minute marginal spine on the posteroinferior part of the pleuron of the third somite, which is produced backward over the fourth somite. The fourth and fifth somites each bears a similar small spine just above the postero-inferior angle. The sixth somite is three times as long as the fifth. The pleuron of the sixth somite is triangular with a very small tooth and the postero-lateral angle is armed with a small but distinct spine (Fig. 7b). The telson is 1.4 times as long as the sixth somite. Its dorsal surface near the base has a large cavity with some plumose hairs and the distal two-thirds is flattened dorsally. There are three pairs of dorsal spines, of which the first two pairs are arranged equidistantly and the distal is situated at the middle point between the second tooth and the posterior margin of the telson. The posterior margin ends in a sharp median point which at each side is armed with three spines and a few plumose hairs (Fig. 7c).

The eye is cylindrical, with a distinct ocellus. The proximal part of the 


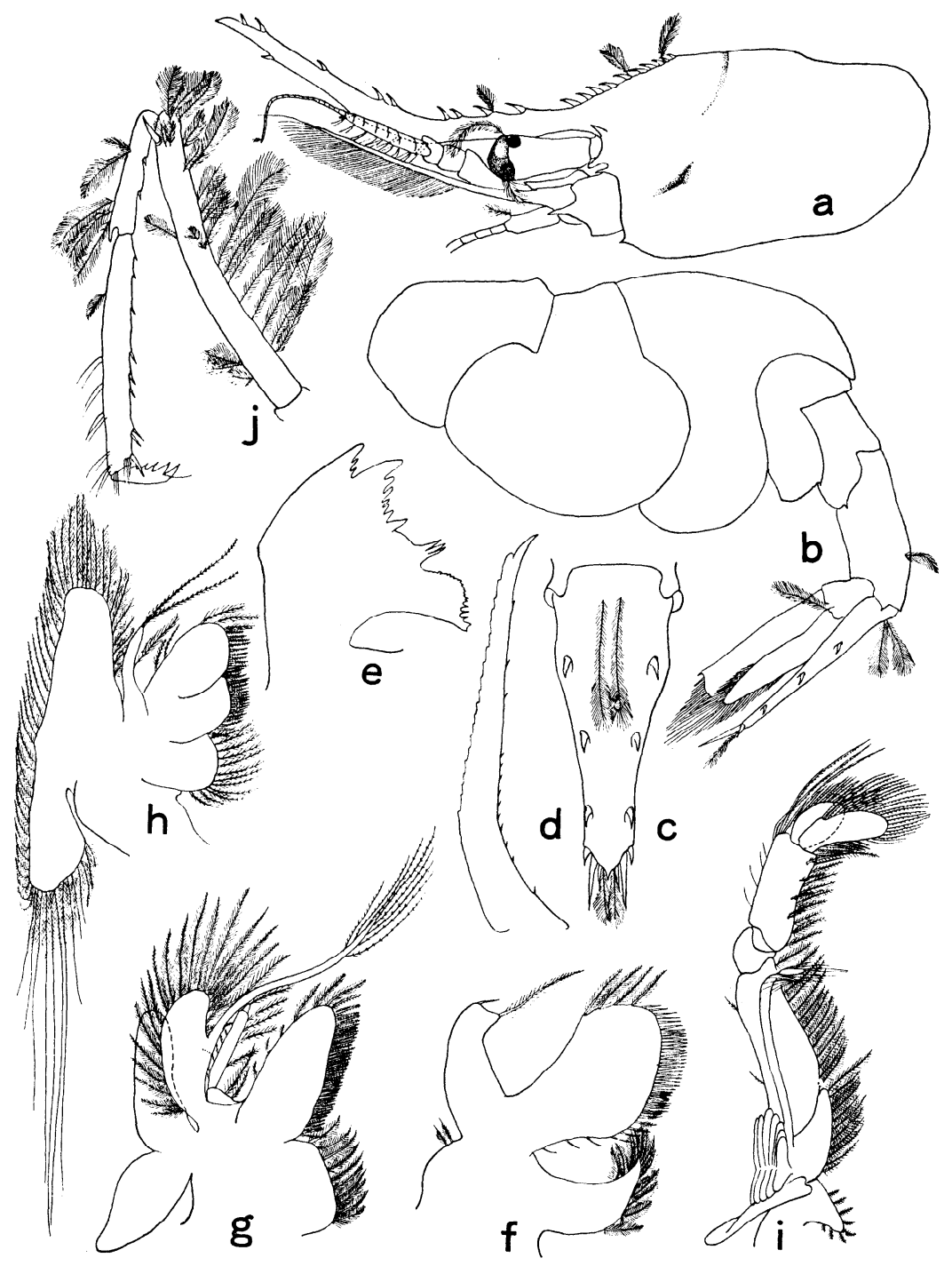

Fig. 7. Neostylodactylus affinis sp. nov.

a, Anterior part of body, $\times 7.2$; b, abdominal somites including telson,

$\times 7.2$; c, telson, $\times 10.2$; d, scaphocerite, $\times 10.2$; e, mandible, $\times 29.7$; $\mathrm{f}$, maxillule, $\times 29.7$; $\mathrm{g}$, first maxilliped, $\times 21.5 ; \mathrm{h}$, maxilla, $\times 21.5$; i, second maxilliped, $\times 14.2 ; \mathrm{j}$, third pereiopod, $\times 10.2$. 
eyestalk is slightly swollen, with two or three small spines on the inner side. The tufts of plumose hairs are present on the border between cornea and stalk.

The antennular peduncle reaches the middle of the rostrum. The basal segment is more than three times as long as the distal two segments combined. The stylocerite reaches the middle of the basal segment and terminates in an acute spine at the outer side. The second and third segments are very short and subequal in length. The antennular flagella are short, reaching as far forward as the rostra1 apex. The outer flagellum is swollen in the proximal seven or eight joints which are sparsely setose, mixed with a few plumose hairs ventrally. The distal part is slender as large as the inner flagellum which also bears plumose hairs on articulation of some joints.

The scaphocerite is very narrow, more than six times as long as wide. The outer margin is concave, with about 15 very fine spinules. The terminal spine extends far beyond the lamella. The basicerite is armed with a strong spine on the outer distal margin and the carpocerite is small (Fig. $7 d)$.

The mandibular palp is absent. The incisor process, which is armed with about ten teeth on the cutting edge and bears a trifoliated process below the teeth, is fused with the molar process which has several small teeth on the cutting edge (Fig. 7e). The maxillule has a tapering proximal endite bearing stout plumose seta. The distal endite is very broad with numerous short stout bristles and a few plumose hairs. The palp is indistinctly bilobed with two, one long and one short, setae (Fig. 7f). The proximal endite of the maxilla is rounded with a few long setae and the distal endite is deeply cleft. The palp is slender and long; the scaphognathite is well developed (Fig. 7h). The first maxilliped has a well-developed exopod with a distinct caridean lobe. The proximal and the distal endites are separated by a deep notch. The palp is long, with several long setae alnog the inner margin, The epipod is largely bilobed (Fig. 7g). The second maxilliped is typical. The distal two segments are placed side by side on the antepenultimate segment. The exopod is well developed and the coxa bears a slender epipod with a podobranch (Fig. 7i). The distal two segments of the third maxilliped are missing and the antepenultimate segment is shorter than the carapace, with long setiferous hairs on the lower border.

The branchial formula is rather different from that of the other species of this family. Only one arthrobranch is present on the third maxilliped.

The first pair of pereiopods is missing. The second pereiopod is provided with long setiferous hairs as in the former species and with long plumose hairs on several segments. The merus is 1.4 times as long as the carpus with five similar spines on the outer surface. The chela is long and slen- 
der, bearing some short spines on the dorsal surface. The palm is extremely short. There are eight slender spines on the outer surface. The last three pereiopods extend to the distal tip of the basal antennular peduncle. The ischio-merus of the third pereiopod is armed with a strong outer spine near the distal articulation, and also bears densely plumose hairs on the dorsal and ventral margins. The carpus is more than half the length of the merus, provided with two small spines on the outer surface and with a few plumose hairs on the dorsal margin. The propodus is more than three times as long as the dactylus and is armed with ten spines on the lower margin, the distal three of these spines are as long as the width of the propodus. The dactylus bears five lower spines excluding the terminal claw (Fig. 7j). The fourth and fifth pereiopods are similar to the third pereiopod. The merus of the fourth pereiopod is armed with only one spine near the distal articulation, as in the third. The dactylus bears six spines on the lower margin excluding the terminal claw. The merus of the fifth pereiopod is armed with two spines; one is placed near the distal articulation, the other on the middle of the segment. There are seven spines excluding the terminal claw on the lower margin of the dactylus.

The endopod of the first pleopod is reduced, it has half the length of the exopod. The second to fifth pleopods are equally biramous with the welldeveloped appendices internae. The uropod considerably exceeds the posterior margin of the telson. The outer margin of the exopod is concave and terminates in a small process with a spine laterally.

Paratypes. The paratypes resemble the holotype in principal characters, but the following minor differences between them were observed.

The rostrum in one specimen is broken off distally. The upper border of the rostrum in the intact specimens is armed with 19 or 20 teeth, of which eight or nine proximal teeth are placed on the carapace. There are four or five teeth on the lower border of the rostrum. The pleuron of the third abdominal somite has a smooth margin without any spines, but those of the fourth and fifth somites each are provided with a small spine just above the postero-inferior angle as in the holotype. Most of the appendages of the three specimens are missing, but the few attached legs are similar to those in the holotype.

The eggs are small, measuring $0.4 \times 0.5 \mathrm{~mm}$ in diameter.

Remarks. The present species is related to $\mathbf{N}$. amarynthis (de Man) but easily distinguished from the latter by the following characters.

1) In the new species the pleura of the first two abdominal somites have smooth margins and those of the following three somites bear only one marginal spine, while in $N$. amarynthis the margins of the first five pleura bear some (three to eight) small spines.

2) The outer surface of the sixth somite in $N$. amarynthis is armed with 
two spines, one situated on the middle of the somite, the other near the small triangular pleura of the somite; these spines are entirely absent in N. affinis.

3) There are only three pairs of spines on the dorsal surface of the telson in the new species, while in $\mathrm{N}$. amarynthis five pairs of dorsal spines are present.

4) The outer spines of the scaphocerite are much smaller in N. affinis than in N. amarynthis.

5) The third maxilliped is provided with only one arthrobranch in $\mathrm{N}$. affinis, while in N. amarynthis two, one normal and one rudimental, arthrobranchs are present on the base of the third maxilliped.

6) The outer margin of the exopod of the uropod in N. affinis ends in two spines, the outer short and fixed, the inner long and movable. The diaeresis is well marked. The endopod of the uropod is normal in shape. In N. amarynthis the outer distal corner is provided with some short hairs and a movable spine, but is destitute of an acute fixed spine. The diaeresis is scarcely marked. There is a distinct lateral process on the outer margin near the base of the endopod of the uropod.

The new species was collected by the research vessel "Yoko Maru" of the Seikai Regional Fisheries Research Laboratory in the Korea Strait. The only other caridean crustaceans collected together with this species is a species of Processa.

\section{N eostylodactylus investigatoris (Kemp)}

Stylodactylus imestigatoris Kemp, 1925, p. 260, figs. 1, 2-Mergui Archipelago.

Material examined.

Tsushima Strait, 34” 00.7' N, 129 $19.4^{\prime}$ E, depth 110 m, June 20, 1964, Time 19: 25, H. Yamashita leg., 1 ovig. 우 (ZLKU No. 11128).

Description. The specimen measures $17 \mathrm{~mm}$ in body length. The rostrum is shorter than the carapace, bearing 19 teeth on the upper border, of which the proximal six teeth are placed on the carapace. The lower border of the rostrum is straight, without any teeth. Supraorbital, antenna1 and pterygostomian spines are present.

The abdomen is bent backward, with smooth margins. The first somite is very narrow dorsally. The third somite has the postero-median part produced over the fourth somite. The pleuron of the fifth somite is not produced posteriorly and the posterior margin is truncated. The telson is slightly longer than the sixth somite, with three pairs of the dorsal spines.

The eye is long, rather compressed, with a small ocellus. The cornea is set obliquely on the stalk in lateral view. The scaphocerite has the outer 
margin with about ten minute spines.

The branchial formula is similar to N. amarynthis, the third maxilliped bears one normal and one rudimental arthrobranch.

The eggs are small, being $0.4 \times 0.5 \mathrm{~mm}$ in diameter.

Remarks. The present specimen agrees with Kemp's original description and illustrations, except for the scaphocerite which has the outer margin bearing a series of about ten minute spines as in N. affinis sp. nov.

This is the second record of the species, the types were collected from the Mergui Archipelago at the depth of $40 \mathrm{fms}$.

\section{Acknowledgements}

We are indebted to the following many carcinologists of the various museums and one university : Dr. J. Forest of the Museum National d'Histoire Naturelle for examining the types of two Atlantic species ; Dr. A. L. Rice and Dr. R. W. Ingle of the British Museum (Natural History) for the examination and illustrations of the types of three species of the Challenger material; Dr. I. Kubo of the Tokyo University of Fisheries for the loan of the type specimen of his new species; Dr. Jan H. Stock of the Amsterdam Museum and Dr. L. B. Holthuis of the Rijksmuseum van Natuurlijke Historie for examining the type specimen of the Siboga species. Further we are in particular grateful to Dr. L. B. Holthuis for reading and criticizing the manuscript, and to Dr. J. Forest for sending a copy of the most valuable reference. Thanks are also due to Dr. B. F. Kensley of the South African Museum for sending many interesting specimens of the South African species, Mr. Hideo Yamashita of the Seikai Regional Fisheries Research Laboratory, Nagasaki and Mr. Akio Taki of the Kyoto University for placing the Japanese specimens at our disposal.

\section{References}

Balss, II., 1914. Ostasiatische Decapoden II. Die Natantia und Reptantia. In: Doflein, F., Beiträge zur Naturgeschichte Ostasiens. Abh. Bayer. Akad. Wiss., suppl. 2 (10) : 1-101, figs. 1-50, pl. 1 .

Balss, II., 1925. Macrura der Deutschen Tiefsee-Expedition. 2 Natantia, Teil A. Wiss. Ergebn. Valdivia Exped., 20: 217-315, figs. 1-75, pls. 20-28.

Balss, H., 1957. Decapoda. Bronns Klassen., 5 (1) : 1505-1672, figs. 1131-1199.

Barnard, K. H., 1950. Descriptive catalogue of South African decapod Crustacea. Ann. S. Afr. Mus., 38 : 1-837, figs. 1-154.

Bate, C. S., 1888. Report on the Crustacea Macrura collected by II. M.S. Challenger during the years 1873-76. Rep. Voy. Challenger, Zool., 24 : i-xc, 1-942, figs. 1-76, pls. $1-150$.

Borradaile, L. A,, 1907. On the classification of the decapod Crustacea. Ann. Mag. nat. Hist., (7) 19: 457-486. 
Calman, W. T., 1939. Crustacea: Caridea. Sci. Rep. John Murray Exped., 6: 183-224, figs. $1-8$.

Holthuis, L. B., 1955. Recent genera of caridean and stenopodean shrimps. 2001. Verh. Leiden, 26: 1-157, figs. 1-105.

Kemp, S., 1925. Notes on Crustacea Decapoda in the Indian Museum, XVII, On various Caridea. Rec. Ind. Mus., 27 : 249-343, figs. 1-24.

Kubo, I., 1942. On two new species of Decapoda Macrura. Annot. 2001. Japon., 21: 30-38, figs. $1-5$.

Man, J. G. de, 1902. Die von Herrn Professor Kiikenthal im Indischen Archipel gesammelten Dekapoden und Stomatopoden. In: Kiikenthal, W., Ergebnisse einer zoologischen Forschungsreise in den Molukken und Borneo. Abh. Senckenb. naturf. Ges., 25: 467-929, pls. 19-27.

Man, J. G. de, 1920. The Decapoda of the Siboga Expedition, Part IV. Families Pasiphaeidae, Stylodactylidae, Hoplophoridea, Nematocarcinidae, Thalassocaridae, Pandalidae, Psalidopodidae, Gnathophyllidae, Processidae, Glyphocrangonidae and Crangonidae. Siboga Exped. Monogr., $39 \mathrm{a}^{3}:$ 1-318, pls. 1-25.

Milne Edwards, A., 1881. Description de quelques Crustacés Macroures provenant des grandes profondeurs de la mer des Antilles. Ann. Sci. nat. Zool., (6) 11 (4): 1-16.

Milne Edwards, A., 1883. Recueil de Figures de Crustacés nouveaux ou peu connus :1-3, pls. 1-44.

Stebbing, T. R. R., 1914. South African Crustacea (Part VII of S. A. Crustacea, for the Marine Investigations in South Africa). Ann. S. Afr. Mus., 15 : 1-55, figs. 1-7, pls. $1-12$.

Thompson, J. R., 1966. Comments on phylogeny of section Caridea (Decapoda, Natantia) and the phylogenetic importance of the Oplophoroidea. Symposium on Crustacea, Part I: $314-326$, fig. 1.

Yokoya, Y., 1933. On the distribution of decapod crustaceans inhabiting the continental shelf around Japan, chiefly based upon the materials collected by S. S. Sôyô-Maru, during the year 1923-30. J. Coll. Agr. Tokyo Imp. Univ., 12 : 1-226, figs. 1-71. 